\title{
Assimilation of carbon from a rotifer by the mussels Mytilus edulis and Perna viridis: a potential food-web link
}

\author{
Wai Hing Wong ${ }^{1}$, Jeffrey S. Levinton ${ }^{1, *}$, Benjamin S. Twining ${ }^{2}{ }^{\text {Nicholas S. Fisher }}{ }^{2}$, \\ Brendan P. Kelaher ${ }^{1}$, Aya K. Alt ${ }^{1}$ \\ ${ }^{1}$ Department of Ecology and Evolution, State University of New York, Stony Brook, New York 11794-5245, USA \\ ${ }^{2}$ Marine Sciences Research Center, State University of New York, Stony Brook, New York 11794-5000, USA
}

\begin{abstract}
We tested the hypothesis that mesozooplankton is a potential food source for 2 marine mussels; the temperate blue mussel Mytilus edulis and the tropical and subtropical green mussel Perna viridis. We fed the rotifer Brachionus plicatilis to each mussel species at 3 rotifer densities $(0.1$, 0.5 , and 1.0 ind. $\mathrm{ml}^{-1}$ ) and found that each mussel species could significantly reduce the abundance of rotifers. We also labeled rotifers by feeding them ${ }^{14} \mathrm{C}$-labeled phytoplankton. The labeled rotifers were fed to mussels at densities of $0.1,0.2,0.5$, and 1.0 individuals $\mathrm{ml}^{-1}$, and the assimilation efficiencies were generally higher at higher rotifer densities (59 to $73 \%$ for $M$. edulis and 37 to $73 \%$ for P. viridis). After standardization for mass and metabolic requirements, we calculated that rotifers make significant contributions to the mussels' energy budgets, which provides quantitative evidence for a potential trophic link between mesozooplankton and marine benthic bivalves. This study demonstrates that mesozooplankton could have an important role in the transformation of energy between benthic and pelagic systems in coastal areas. Dense populations of bivalves could exert a strong top-down effect on planktonic food webs.
\end{abstract}

KEY WORDS: Benthic suspension feeders $\cdot$ Zooplankton $\cdot$ Trophic linkage $\cdot$ Rotifera $\cdot$ Bivalvia

\section{INTRODUCTION}

Filter-feeding bivalve populations exert keystone effects on coastal plankton by filtering large volumes of water, thereby severely depleting the phytoplankton (Officer et al. 1982, Dame 1996, Prins et al. 1998). Energy balance and therefore somatic growth in suspension-feeding bivalves can also be affected by the interactions of some environmental variables, mainly food supply and water temperature (Bayne 1976), as well as influenced by tidal elevation, because of changing feeding time and depletion of foods in the benthic boundary layers (Peterson \& Black 1987).

Bivalves are assumed to be herbivores and phytoplankton are considered to be the major primary source of nutrition (Page \& Hubbard 1987). Because of the spatial and temporal variations in production, phyto- plankton abundance may be insufficient to maintain bivalve growth and reproduction (Asmus et al. 1990). Adult bivalves have been shown to assimilate many kinds of food, including dissolved sources (Jörgensen 1983, Gorham 1988, Roditi et al. 2000), bacteria (Crosby et al. 1990, Langdon \& Newell 1990, Kreeger \& Newell 1996, 2001), and heterotrophic nanoflagellates (Sherr et al. 1986, Langdon \& Newell 1990, Kreeger \& Newell 1996, 2001). But the importance of larger zooplankton, particularly mesozooplankton, as a source of nutrition for bivalves has been rarely tested quantitatively in marine systems.

In freshwater, it has been shown that the zebra mussel Dreissena polymorpha can capture and assimilate micro- and mesozooplanktonic rotifers, and that this food source can be an important part of the mussel's energy budget (Wong et al. 2003). Despite the lack of 
quantitative estimates in marine systems, there is growing evidence to support the hypothesis that mesozooplankton is a potential food source for bivalves. In San Francisco Bay the invasion of the clam Potamocorbula amurensis was associated with the decline in abundance of 3 common estuarine copepod species, owing to the probable consumption of naupliar stages (Kimmerer et al. 1994). It has also been demonstrated that other zooplankton could be removed by bivalves (Carlson et al. 1984, Horsted et al. 1988, Riemann et al. 1990). Furthermore, the oyster Crassostrea gigas, when fed a natural planktonic community from the Mediterranean, was able to retain some large zooplankton including bivalve veligers, tintinnids, copepoda nauplii, appendicularia, and rotifers (Dupuy et al. 2000b). Field and laboratory experiments have also demonstrated that mollusks and crustaceans, up to 3-6 mm, could be ingested by Mytilus edulis (Davenport et al. 2000).

We know of no quantitative evidence of assimilation of carbon from mesozooplankton by marine bivalves, even though some micro- and mesozooplankton species have been shown to be cleared from suspension (Horsted et al. 1988, Davenport et al. 2000, Dupuy et al. $2000 \mathrm{~b}$ ) and some zooplankton have been found in the digestive tract of marine bivalves (Shumway et al. 1987, Jasprica et al. 1997). This study was an attempt to quantitatively estimate the assimilation of carbon from mesozooplanktonic rotifers by 2 common species of marine mussels.

\section{MATERIALS AND METHODS}

Experimental animals. The temperate blue mussel Mytilus edulis and the tropical and subtropical green mussel Perna viridis were used to test the hypothesis that mussels can assimilate carbon from mesozooplankon. $M$. edulis is widely distributed in the northern hemisphere (Seed 1976); experimental individuals, whether used for measurements of assimilation (length $29.25 \pm 0.28 \mathrm{~mm}$, mean $\pm \mathrm{SE} ; \mathrm{n}=39$ ), or for retention (length $39.00 \pm 0.33$, weight $0.466 \pm 0.018 \mathrm{~g}$, mean $\pm \mathrm{SE}$; $\mathrm{n}=18$ ), were obtained from intertidal localities near Stony Brook, New York in April 2002. P. viridis is usually distributed from the Persian Gulf to the southwest Pacific longitudinally and from southern Japan to Papua New Guinea latitudinally (Siddall 1980). Recently, it has also been found in the USA (Benson et al. 2001, Ingrao et al. 2001). Green mussels (length 29.14 $\pm 0.35 \mathrm{~mm}$, weight $0.102 \pm 0.006 \mathrm{~g}$, mean $\pm \mathrm{SE}_{;} \mathrm{n}=21$ ), were collected in a mid-intertidal area in Tampa Bay, Florida in March 2002.

Before the feeding experiment, all mussels were acclimated to laboratory conditions for about $2 \mathrm{wk}$ in a recirculating seawater system (temperature $20^{\circ} \mathrm{C}$, salinity $31 \mathrm{ppt}$ ). During this time, the mussels were fed ad lib on Isochrysis INSTANT ALGAE ${ }^{\circledR}$ (Reed Mariculture).

Rotifer cysts of Brachionous plicatilis were obtained from Florida Aqua Farms and were hatched in the laboratory, and fed on the chlorophyte Dunaliella tertiolecta (culture CCMP 1312). The rotifers were $255.8 \pm$ $17.9 \mu \mathrm{m}$ (mean $\pm \mathrm{SE}, \mathrm{n}=13$ ) in length and $0.744 \pm$ $0.021 \mu \mathrm{g}$ (mean $\pm \mathrm{SE}, \mathrm{n}=3$ ) in mass.

Experimental protocol for rotifer assimilation. The assimilation of carbon from zooplankton by benthic suspension feeders was tested by feeding radiolabeled cultures of rotifers to mussels. On the first day, $370 \mathrm{kBq}$ of ${ }^{14} \mathrm{C}\left(\mathrm{NaH}^{14} \mathrm{CO}_{3}\right.$, in sterile filtered seawater) was added to $500 \mathrm{ml}$ of Dunaliella tertiolecta suspension, where the initial concentration of $D$. tertiolecta was 2.0 to $5.0 \times 10^{5}$ cells ml ${ }^{-1}$ (corresponding to $3.1-7.7 \mathrm{mg}$ dry mass $\mathrm{l}^{-1}$ ). After $3 \mathrm{~d}$, the cells were uniformly labeled (Wang \& Fisher 1996), and rotifers were added to the labeled cell suspension. After $3 \mathrm{~h}$, labeled rotifers were sieved out and, in order to purge any undigested ${ }^{14} \mathrm{C}$ label from the rotifer guts, resuspended in unlabeled microalgae for $25 \mathrm{~min}$, which is longer than rotifer-gut-passage time (Starkweather \& Gilbert 1977). It was therefore assumed that labeled algae in the gut had been evacuated before depurated rotifers were collected by filtering through a $64 \mu \mathrm{m}$ net. An aliquot of the depurated rotifers was dyed with $5 \%$ Lugol's, and observed under a microscope at $25 \times$. Only rotifers were found in the suspension. Rotifer fecal pellets and microalgae were much smaller than $64 \mu \mathrm{m}$ and had passed through the net. The filtered rotifers were then washed twice with filtered Long Island Sound seawater (GF-C filter) for 15 to $20 \mathrm{~min}$ and concentrated into a $50 \mathrm{ml}$ beaker containing filtered seawater. In coastal waters, the density of rotifers is usually $<1$ individual $\mathrm{ml}^{-1}$ (Park \& Marshall 2000). Four rotifer densities $\left(0.1,0.2,0.5\right.$, and 1.0 ind. $\left.\mathrm{ml}^{-1}\right)$ were used in our experiment. For each mussel species, 4 individuals were used in each rotifer density treatment. Each mussel was put into a $1000 \mathrm{ml}$ beaker filled with $500 \mathrm{ml}$ of filtered seawater. The appropriate rotifer density was achieved by adding different volumes of concentrated rotifers to the suspension at time zero. Rotifer densities were readjusted to timezero levels every 15 min (Roditi \& Fisher 1999). Just before the labeled rotifers were added to the beaker, unlabeled $D$. tertiolecta at 1.0 to $2.0 \times 10^{5}$ cells ml $^{-1}$ were suspended into the $500 \mathrm{ml}$ filtered seawater. Mussels were collected after $30 \mathrm{~min}$ feeding and moved to new filtered seawater for depuration. During depuration, unlabeled rotifers and microalgae were fed to mussels. After depuration, the mussels 
were dissected separately. The ${ }^{14} \mathrm{C}$ activity in rotifers and the whole mussel soft tissue, as well as in the fecal pellets during the depuration period, was determined with a Packard Tri-Carb 2100TR liquid scintillation analyzer after being dissolved in Solvable (NEN Research Product) at $60^{\circ} \mathrm{C}$ overnight. After cooling, the scintillant (Ultima Gold XR, Packard) was added to these samples. A vial without sample, containing Solvable and scintillant only, was used as a control. The assimilation efficiency was calculated as:

$$
\mathrm{AE}(\%)=\frac{{ }^{14} \mathrm{C}_{\text {tissue }}}{{ }^{14} \mathrm{C}_{\text {tissue }}+{ }^{14} \mathrm{C}_{\text {feces }}} \times 100
$$

where ${ }^{14} \mathrm{C}_{\text {tissue }}$ is the ${ }^{14} \mathrm{C}$ radioactivity in the tissue after $72 \mathrm{~h}$ of depuration, and ${ }^{14} \mathrm{C}_{\text {feces }}$ is the ${ }^{14} \mathrm{C}$ radioactivity in the cumulative feces collected during $72 \mathrm{~h}$ of depuration. During the experimental time course, unlabeled rotifers and unlabeled Dunaliella were fed to mussels and no pseudofeces were found. With this method, we assumed that the respiratory loss of ${ }^{14} \mathrm{C}$ was negligible within the first $24 \mathrm{~h}$ (Wang \& Fisher 1996).

Experimental protocol for rotifer retention. Three densities of rotifers $\left(0.1,0.5\right.$, and 1.0 ind. $\left.\mathrm{ml}^{-1}\right)$ were used in a retention experiment. We used 16 beakers for each rotifer density, each containing 1 mussel, $800 \mathrm{ml}$ filtered natural seawater, and Dunaliella tertiolecta at a density of 1.0 to $2.0 \times 10^{5}$ cells ml $^{-1}$. Eight more beakers, each without mussels, were used as controls. The experimental feeding time was $2 \mathrm{~h}$. At $30 \mathrm{~min}$ intervals after the experiment began, a mussel was removed from 1 beaker of each density treatment and $5 \%$ formalin with Rose Bengal stain $(0.01 \%$ Rose Bengal) was added to the beaker in order to preserve and facilitate visual counting of rotifers. At the same time, 2 control beakers were also terminated by adding similar amounts of $5 \%$ formalin and stain. During the experiment, all the mussels were actively opening their valves. Rotifer abundance in the water columns (\% relative to starting concentrations [100\%]) was calculated as:

$$
\frac{C_{t}}{C_{0}} \times 100
$$

where $C_{0}$ is the initial density of rotifers (ind. $\mathrm{ml}^{-1}$ ) at time zero, and $C_{t}$ is the density at time $t(t=0.5 \mathrm{~h}$, $1.0 \mathrm{~h}, 1.5 \mathrm{~h}$, and $2.0 \mathrm{~h}$, respectively). For calculation, the average of the 4 experimental replicates was obtained and the mean of the control at each time interval was used. Assuming the mussels had 100\% retention efficiency (Bayne \& Widdows 1978, Dupuy et al. 1999), clearance rate (CR: $1 \mathrm{~h}^{-1}$ mussel $^{-1}$ ) was calculated from changes in the average rotifer density. We selected 30 min as the time for the CR calculation to make sure that $\mathrm{CR}$ corresponded to the assimilation experimental time course of $30 \mathrm{~min}$. The $\mathrm{CR}$ of each mussel was calculated as follows (Coughlan 1969):

$$
\mathrm{CR}=\frac{\ln C_{0}-\ln C_{t}}{T} \times V
$$

where $V$ is the volume of the suspension (l), $T$ the is time in $\mathrm{h}, C_{0}$ is the initial density of rotifers (ind. $\mathrm{l}^{-1}$ ), and $C_{t}$ is the density at time $0.5 \mathrm{~h}$ (ind. $^{-1}$ ).

Standardization, calculation of absorption rate on rotifers, and scope for growth. In order to compare the energy absorption by mussels from rotifers, clearance rate was standardized to that of a standard mussel of $1 \mathrm{~g}$ dry tissue mass by means of the following relationship (Bayne et al. 1987):

$$
\mathrm{CR}_{\text {standard }}=\mathrm{CR}_{\exp } \times\left(\frac{\mathrm{DW}_{\text {standard }}}{\mathrm{DW}_{\exp }}\right)^{\mathrm{b}}
$$

where $\mathrm{CR}_{\text {standard }}$ and $\mathrm{CR}_{\text {exp }}$ are the standardized and experimental $\mathrm{CR}\left(\mathrm{l} \mathrm{h}^{-1}\right)$, and $\mathrm{DW}_{\exp }$ and $\mathrm{DW}_{\text {standard }}$ are the dry tissue weights $(\mathrm{g})$ of the experimental and standard mussels, respectively. The coefficient $\mathrm{b}$ is 0.66 for Mytilus edulis (Møhlenberg \& Riisgard 1979) and is 0.64 for Perna viridis in the spring season (Wong \& Cheung 2001). The filtration rate of a standard mussel (FR: rotifer individuals $\mathrm{h}^{-1} \mathrm{~g}^{-1}$ ) was then estimated by multiplying $\mathrm{CR}_{\text {standard }}$ by rotifer density. Since there were no visible pseudofeces during the experiment, ingestion rate of the mussel (IR: rotifer individuals $\mathrm{h}^{-1} \mathrm{~g}^{-1}$ ) was assumed to be equal to the filtration rate. Rotifer mass was converted to the average energy content per rotifer using the average of the pooled determination of $22.40 \mathrm{~J} \mathrm{mg}^{-1}$ in Brachionus species (Yúrera et al. 1997). Therefore, absorption rate of a standard mussel (AR: $\mathrm{J} \mathrm{h}^{-1}$ ) could be calculated as $\mathrm{AR}=\mathrm{IR} \times \mathrm{AE}$ in which the correspondent IR and $\mathrm{AE}$ were used to determine the absorption rate at different rotifer densities.

The routine metabolic rate (RMR: $\mathrm{J} \mathrm{h}^{-1}$ ) of a mussel of dry soft tissue mass equal to $1 \mathrm{~g}$ is $4.71 \mathrm{~J} \mathrm{~h}^{-1}$ for Mytilus edulis (Bayne et al. 1989) and $3.13 \mathrm{~J} \mathrm{~h}^{-1}$ for Perna viridis (W. H. Wong \& S. G. Cheung unpubl. data) respectively. Scope for growth (SFG: $\mathrm{J} \mathrm{h}^{-1}$ ) was estimated as:

$$
\mathrm{SFG}=\mathrm{AR}-[\mathrm{RMR}+(0.064 \times \mathrm{AR})]
$$

where AR is the absorption rate, RMR is the routine metabolic rate and 0.064 is the assumed proportion of the absorbed ration that is lost via excretion, which is based on the data measured for $M$. edulis (Bayne \& Newell 1983). The ratio of AR to RMR $\times 100$ was computed to evaluate the percentage contribution of absorption relative to the RMR.

An analysis of variance (ANOVA) was used to investigate the effects of mussel species and rotifer density on the assimilation efficiency and to compare the difference between CR within 1 species. Linear re- 
gression was estimated to examine the relationship between rotifer density and AR of the 2 mussels, and the slope comparison between the 2 lines was performed following the method in Zar (1996).

\section{RESULTS}

\section{Assimilation of carbon from rotifers by mussels}

At rotifer densities of $0.1,0.2,0.5$, and 1.0 ind. $\mathrm{ml}^{-1}$, the corresponding assimilation efficiencies (mean \pm $\mathrm{SE}, \mathrm{n}=4$ ) of Mytilus edulis were $66.39 \pm 3.84 \%$, $59.18 \pm 5.03 \%, 73.21 \pm 5.15 \%$, and $70.56 \pm 2.76 \%$, respectively, while the assimilation efficiencies of Perna viridis were $37.08 \pm 5.88 \%, 64.81 \pm 1.67 \%, 69.94 \pm$ $3.73 \%$, and $72.80 \pm 2.33 \%$, respectively (Fig. 1). There was a significant interaction between the effect of rotifer density and species of mussels on assimilation efficiency (Table 1). Efficiency of $M$. edulis was not affected by rotifer density (SNK, p > 0.05, Fig. 1). However, the assimilation efficienciy for $P$. viridis was significantly lower at the smallest density of rotifer than at higher rotifer densities (SNK, p < 0.05), which did not differ significantly (SNK, p > 0.05, Fig. 1).

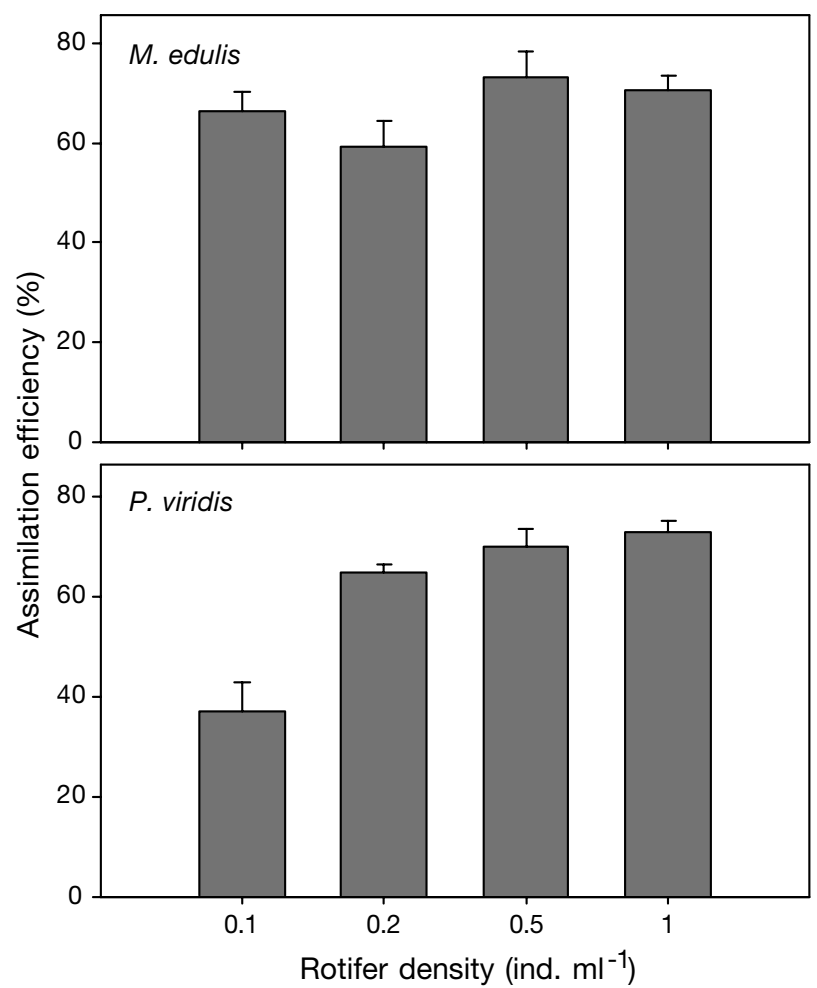

Fig. 1. Mytilus edulis and Perna viridis. Assimilation efficiencies of the blue mussel (top panel) and the green mussel (bottom panel) as a function of rotifer density. Mean and SE are shown

\section{Retention and clearance rates (CR) of mussels feeding on rotifers}

Rotifer abundances in the presence of Mytilus edulis and Perna viridis were significantly lower than in the controls. The rotifer abundance decreased with time in the experimental groups, while it remained

Table 1. Effects of mussel species and rotifer density on the assimilation efficiency

\begin{tabular}{|lrccc|}
\hline Source & df & MS & $F$ & $\mathrm{p}$ \\
\hline Mussel species (A) & 1 & 0.072 & 3.925 & 0.059 \\
Rotifer density (B) & 3 & 0.031 & 9.271 & $0.000^{\mathrm{a}}$ \\
$\mathrm{A} \times \mathrm{B}$ & 3 & 0.050 & 6.455 & $0.002^{\mathrm{a}}$ \\
Residual & 24 & 0.008 & & \\
${ }^{\mathrm{a}} \mathrm{p}<0.01$ & & & & \\
\hline
\end{tabular}

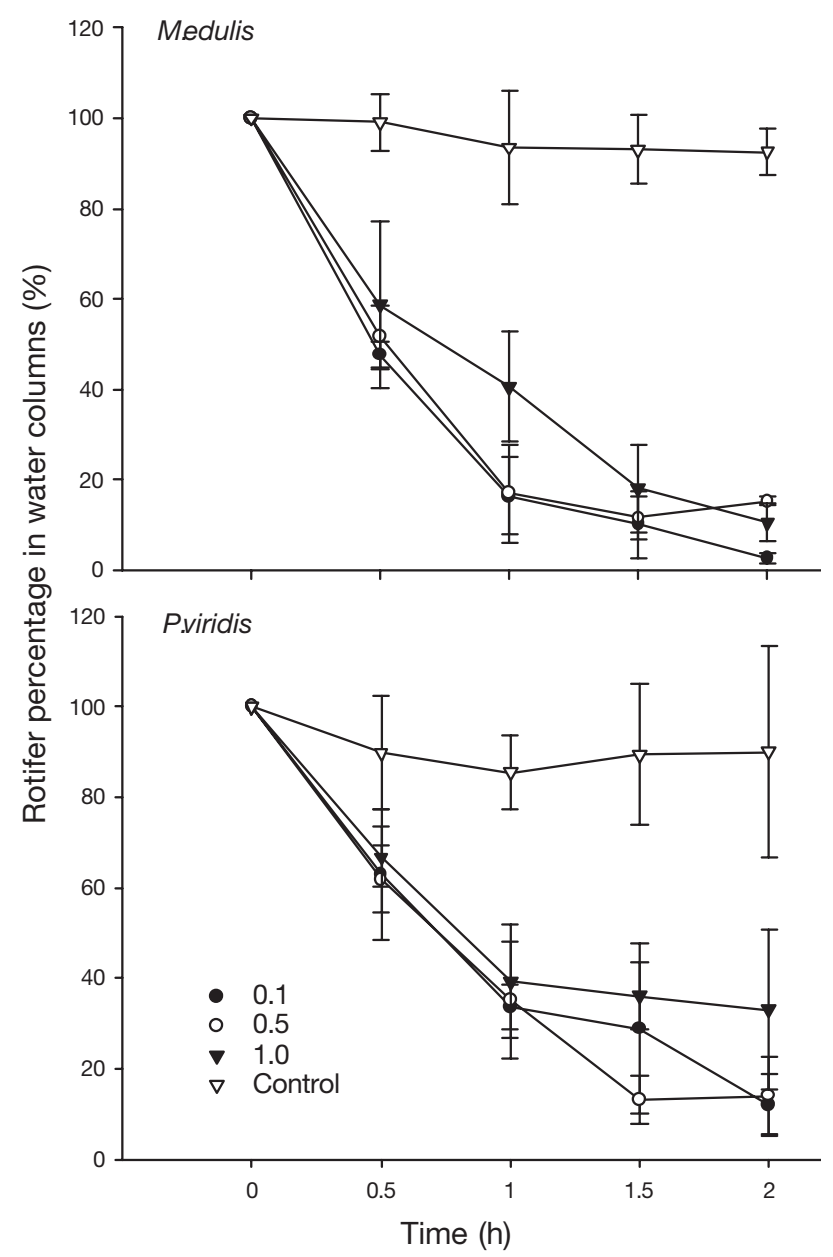

Fig. 2. Time course of rotifer abundance (\%) in experimental and control $(\nabla)$ suspensions (with and without mussels, respectively) at rotifer densities of $0.1(\bullet), 0.5(0)$ and $1.0(\mathbf{v})$ ind. $\mathrm{ml}^{-1}$. Mean $\pm \mathrm{SD}$ are shown 


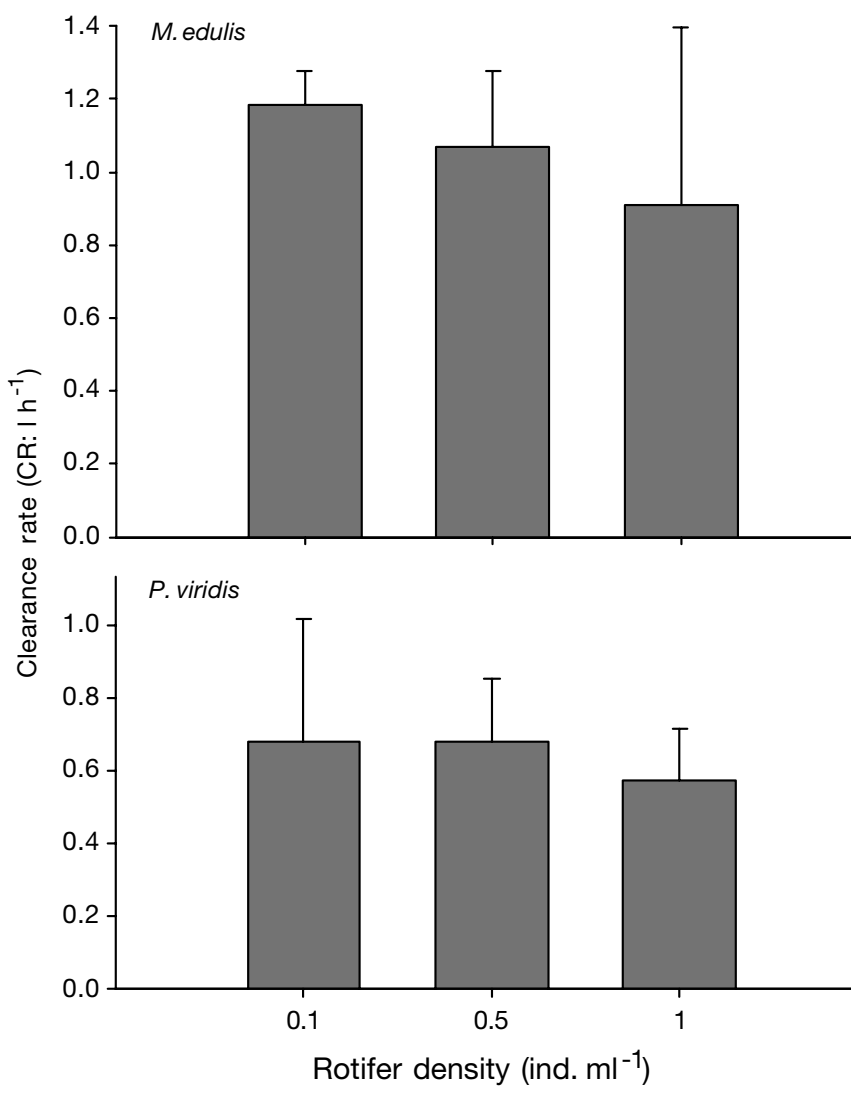

Fig. 3. Mytilus edulis and Perna viridis. Clearance rate of the blue mussel (top panel) and the green mussel (bottom panel) at different rotifer densities. Mean and SD are shown
Table 2. Mytilus edulis and Perna viridis. Scope for growth (SFG: $\mathrm{J} \mathrm{h}^{-1}$ ) and ratio of absorption rate to routine metabolic rate (AR/RMR: \%). Mean \pm SE are shown

\begin{tabular}{|lccc|}
\hline Mussel & $\begin{array}{c}\text { Rotifer density } \\
\left.\text { (ind. } \mathrm{ml}^{-1}\right)\end{array}$ & SFG $\left(\mathrm{J} \mathrm{h}^{-1}\right)$ & AR/RMR (\%) \\
\hline M. edulis & 0.1 & $0.39 \pm 0.19$ & $115.8 \pm 4.4$ \\
& 0.5 & $20.62 \pm 2.47$ & $574.6 \pm 56.0$ \\
& 1.0 & $36.89 \pm 11.12$ & $943.6 \pm 252.2$ \\
$P$. viridis & 0.1 & $4.20 \pm 1.79$ & $250.1 \pm 61.1$ \\
& 0.5 & $65.92 \pm 8.72$ & $2356.8 \pm 297.8$ \\
& 1.0 & $117.65 \pm 15.24$ & $4122.8 \pm 520.1$ \\
\hline
\end{tabular}

\section{Absorption rates (AR) and scope for growth (SFG) of mussels feeding on rotifers}

At rotifer densities of $0.1,0.5$, and 1.0 ind. $\mathrm{ml}^{-1}$, the $\mathrm{AR}\left(\mathrm{J} \mathrm{h}^{-1}\right)$ of a $1 \mathrm{~g}$ standard blue mussel Mytilus edulis were estimated to be $5.45 \pm 0.21,27.06 \pm 2.64$, and $44.4 \pm 11.88$, respectively, while for a $1 \mathrm{~g}$ standard green mussel Perna viridis, they were $7.83 \pm 1.91$, $73.77 \pm 9.32$, and $129.04 \pm 16.28$, respectively. $A R_{\text {, }}$ therefore, increased linearly with increase in rotifer density for each species of mussel (Fig. 4). Because the slope of the graph is higher for the green mussel than for the blue mussel, we conclude that the green mussel can extract more energy from the rotifers at the same rotifer density between the range of 0.1 to $1.0(\mathrm{n}=20$, $t=4.55, \mathrm{p}<0.01)$.

SFG $\left(\mathrm{J} \mathrm{h}^{-1}\right)$ of the blue mussel Mytilus edulis ranged from 0.39 to 36.89 and SFG of the green mussel Perna viridis ranged from 4.20 to 117.65 (Table 2). This reveals that each mussel species would achieve a pos- unchanged in the control (Fig. 2). In the first hour, the abundance decreased sharply from 100 to ca. $25 \%$ in $M$. edulis and to ca. $36 \%$ in $P$. viridis at all 3 experimental densities. After this initial decrease, however, the density of rotifers became relatively constant.

At rotifer densities of $0.1,0.5$, and 1.0 ind. $\mathrm{ml}^{-1}$, the corresponding $\mathrm{CR}$ $\left(\right.$ mean $\pm \mathrm{SE}, 1 \mathrm{~h}^{-1}$ ) of Mytilus edulis (calculated from data after $30 \mathrm{~min}$ ) were $1.18 \pm 0.05,1.07 \pm 0.10$, and $0.91 \pm 0.24$, respectively (Fig. 3), but there was no significant difference among them (ANOVA, $\mathrm{n}=12, F=$ 0.803, $p>0$. 05). The corresponding $\mathrm{CR}$ (mean $\pm \mathrm{SE}, \mathrm{l} \mathrm{h} \mathrm{h}^{-1}$ ) for Perna viridis were $0.68 \pm 0.17,0.68 \pm 0.09$, and $0.57 \pm 0.07$, respectively and, similarly, no significant differences were detected (ANOVA, $\mathrm{n}=12$, $F=0.294, \mathrm{p}>0.05)$.

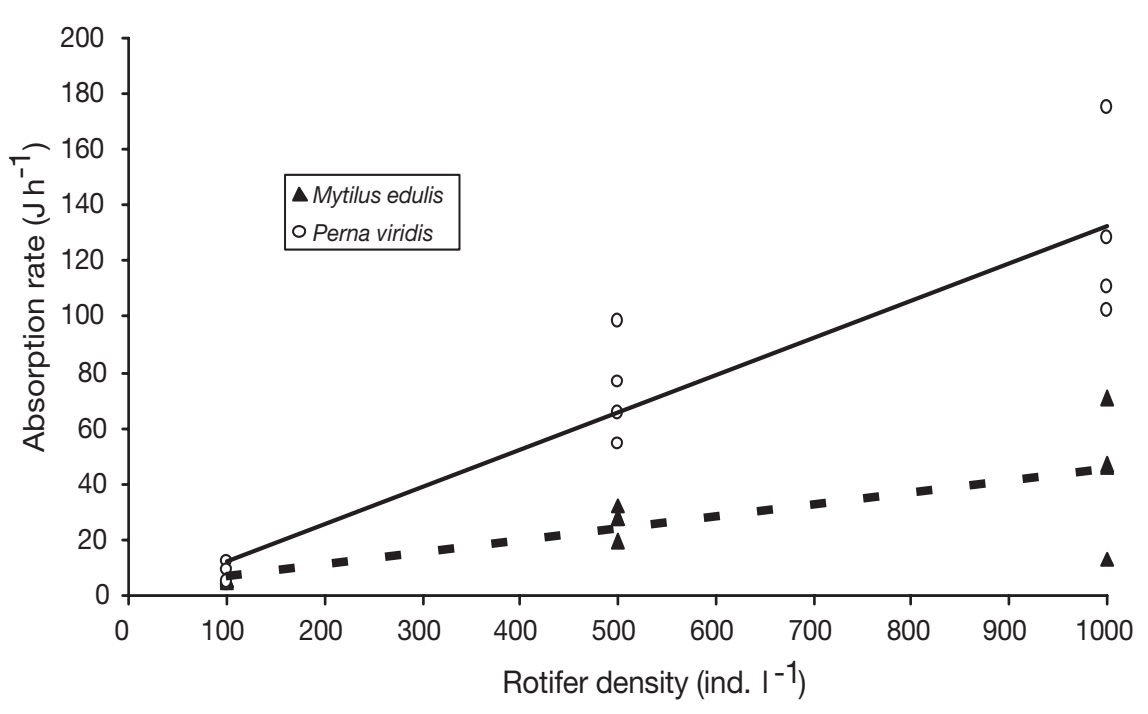

Fig. 4. Mytilus edulis and Perna viridis. Absorption rates of mussels at different rotifer densities. The 2 equations are: $M$. edulis, $\mathrm{AR}=0.043 \times$ (rotifer density) + $2.736, \mathrm{R}^{2}=0.622, \mathrm{n}=12, \mathrm{p}<0.01 ; P$. viridis, $\mathrm{AR}=0.134 \times$ (rotifer density) -1.090 , $\mathrm{R}^{2}=0.862, \mathrm{n}=12, \mathrm{p}<0.01$ 
itive SFG if rotifers were their only food resource. Given that rotifer density in tidal freshwater and estuarine waters is usually around 0.1 ind. $\mathrm{ml}^{-1}$ (Park \& Marshall 2000), rotifers can contribute $0.39 \mathrm{~J} \mathrm{~h}^{-1}$ to $4.20 \mathrm{~J} \mathrm{~h}^{-1}$ to the SFG of the blue mussel and green mussel, respectively. Under rotifer density of 0.1 ind. $\mathrm{ml}^{-1}$, the ratios of AR/RMR were 115.8 and $250.1 \%$ respectively (Table 2) which shows that the absorbed energy from rotifers is more than enough to maintain the routine metabolism of these 2 mussels. The ratio of $A R / R M R$ increased with increasing rotifer density (Table 2).

\section{DISCUSSION}

This study clearly demonstrates the potential for a trophic link between mesozooplankton and marine benthic bivalves, because the 2 experimental mussel species grazed and assimilated rotifers. Assimilation efficiencies of the marine bivalves feeding on rotifers (37 to $73 \%$ ) were higher than that in the freshwater zebra mussel Dreissena polymorpha, when fed the rotifers Brachionus calyciflorus (ca. $210 \mu \mathrm{m}$ long) and Lepadella ovalis (ca. $140 \mu \mathrm{m}$ long) (Wong et al. 2003). Our preliminary observations using video endoscopy suggest that rotifers can escape capture by mussel latero-frontal cilia, which might mean that retention of rotifers is inefficient. Some of the inefficiency of oysters has been attributed to the active swimming behavior of Uronema (ciliate), which allowed some of the experimental animals in one study to escape the strong inhalant current of the bivalves (Le Gall et al. 1997). Nevertheless, even at the density of 0.1 ind. $\mathrm{ml}^{-1}$, the energy contribution of rotifers to mussels was still sufficient to produce a positive SFG (Table 2).

Planktonic rotifers form an important constituent in the diets of many aquatic predators, such as other rotifers, insect larvae, cyclopoid and calanoid copepods, malacostracans, and particulate-feeding and filter-feeding fish (Stemberger \& Gilbert 1987), but rotifers are rarely reported as a food source for bivalves. Our results show that they are also a possible nutritional resource of bivalves, whether in freshwater or in the marine system, as demonstrated by studies on zebra mussels (Wong et al. 2003) and the 2 marine species in this experiment.

Apart from mesozooplankton, nano- and microzooplankton have been shown to be available food sources for bivalves. For example, nanoflagellates, ciliates, and small rotifers are all assimilated by bivalves (Sherr et al. 1986, Langdon \& Newell 1990, Kreeger \& Newell 1996, 2001, Wong et al. 2003). It can be predicted that nano- and microzooplankton may play a more important role in the aquatic environment since they are much more abundant than mesozooplankton in numbers and biomass (Stelfox et al. 1999). Of particular importance are the ciliates and flagellates, which can not only be directly consumed by bivalves (Dupuy et al. 2000a,b), but also act as a trophic link between bacterioplankton and benthic suspension feeders (Le Gall et al. 1997, Dupuy et al. 1999, Loret et al. 2000).

We suggest that suspension-feeding bivalves should retain lower numbers of larger and mobile zooplankton, though larger animals $<3$ to $6 \mathrm{~mm}$ have been reported to be ingested by mussels occasionally (Davenport et al. 2000). Marine enclosure experiments showed that Mytilus edulis reduced the number of tintinnid cilliates and rotifers, but the abundance of larger zooplankton, like adults of the copepod Acartia tonsa were less affected (Horsted et al. 1988). While smaller mesozooplankton were strongly reduced, the zebra mussel did not affect copepods when it invaded the Hudson River (Pace et al. 1998). Field studies show that naupliar stages of copepods, in contrast to adults, appear to be vulnerable to bivalve grazing (Kimmerer et al. 1994, Pace et al. 1998). A laboratory study, however, failed to demonstrate successful clearance of copepod nauplii (MacIsaac et al. 1995). One study showed greater filtering of micro- and mesozooplankton than heterotrophic nanoflagellates (Riemann et al. 1990). More experiments need to be done to resolve the role of size and mobility in determining the accessibility of zooplankton as food for suspension-feeding bivalves.

Cannibalism of bivalves on their own larvae may be an important factor in bivalve population dynamics and larval recruitment. Cannibalism on zebra mussel larvae has been shown in the laboratory (MacIsaac et al. 1991, 1995) and field experiments have demonstrated that Cerastoderma edule and Mya arenaria adults could reduce the settlement of bivalve larvae by up to 40 and $20 \%$, respectively (Andre \& Rosenberg 1991). In the Adriatic Sea, Mytilus galloprovincialis was shown to ingest bivalve larvae, along with other zooplankton (Jasprica et al. 1997). It is likely that early larval stages are more vulnerable than later shelled larval stages. Assimilation experiments still need to be performed.

Previous studies suggest a strong degree of selectivity by bivalves among phytoplankton sources and between phytoplankton and nonliving sources such as vascular plant detritus (Shumway et al. 1985, Ward et al. 1997, Baker et al. 1998). Studies to measure absorption of zooplankton by bivalves when in mixtures with phytoplankton species are needed to determine whether zooplankton are selected preferentially, relative to different phytoplankton species.

So far, it has been shown that suspension-feeding bivalves can derive nutrition from dissolved organic 
matter (Manahan et al. 1983, Roditi et al. 2000), sediment detritus (Crosby et al. 1990, Langdon \& Newell 1990, Kreeger \& Newell 2001), phytoplankton and bacteria (Kreeger \& Newell 2001), as well as many kinds of zooplankton. The last resource includes heterotrophic nanoflagellates (3 to $8 \mu \mathrm{m}$ ) (Kreeger \& Newell 2001), ciliates $(20 \mu \mathrm{m})$ (Le Gall et al. 1997), protists (30 to $136 \mu \mathrm{m})$ (Loret et al. 2000), rotifers (140 to $256 \mu \mathrm{m}$ ) (this study, Wong et al. 2003), as well as other zooplankton (138 to $518 \mu \mathrm{m}$, Dupuy et al. 2000b, 100 to $1000 \mu \mathrm{m}$, Davenport et al. 2000), and coccasionally animals $<3000$ to $6000 \mu \mathrm{m}$ (Davenport et al. 2000). This enlarged food spectrum of bivalves suggests that they are usually generalist grazers (Asmus \& Asmus 1991). Therefore, the trophic linkage between benthic suspension feeders and a wide variety of water-column food sources (most notably zooplankton, as well as planktonic larvae and nauplii) has been underestimated in past ecological studies. Instead of feeding solely on phytoplankton, which would reduce food for herbivorous zooplankton, bivalves may exert a topdown effect by preying directly on zooplankton. The role of these crucial water-column groups in suspension-filter-feeding bivalve nutrition may therefore need to be elucidated with more studies in the future.

Acknowledgements. This work was supported by the Hudson River Foundation (00798A) and the US National Science Foundation (OCE 9811380). We thank Patrick Baker for collecting mussels. Bengt Allen and Stephen Baines provided laboratory support. Finally, all 5 reviewers' comments are appreciated for improving the quality of the manuscript.

\section{LITERATURE CITED}

Andre C, Rosenberg R (1991) Adult-larval interactions in the suspension-feeding bivalves Cerastoderma edule and Mya arenaria. Mar Ecol Prog Ser 71:227-234

Asmus RM, Asmus H (1991) Mussels beds: limiting or promoting phytoplankton? J Exp Mar Biol Ecol 148:215-232

Asmus H, Asmus RM, Reise K (1990) Exchange processes in an intertidal mussel bed: a Sylt-flume study in the Wadden Sea. Ber Biol Anst Helgoland 6:1-79

Baker SM, Levinton JS, Kurdziel JP, Shumway SE (1998) Selective feeding and biodeposition by zebra mussels and their relation to changes in phytoplankton composition and seston load. J Shellfish Res 17:1207-1213

Bayne BL (1976) Marine mussels: their ecology and physiology. Cambridge University Press, Cambridge

Bayne BL, Newell RC (1983) Physiological energetics of marine molluscs. In: Saleuddin ASW, Wilbur KM (eds) The Mollusca, Vol 4, Physiology (Part 1). Academic Press, New York, p 407-515

Bayne BL, Widdows J (1978) The physiological ecology of two populations of Mytilus edulis L. Oecologia 37:137-162

Bayne BL, Hawkins AJS, Navarro E (1987) Feeding and digestion by the mussel Mytilus edulis L. (Bivalvia: Mollusca) in mixtures of silt and algal cells at low concentrations. J Exp Mar Biol Ecol 111:1-22

Bayne BL, Hawkins AJS, Navarro E, Iglesias JIP (1989)
Effects of seston concentration on feeding, digestion and growth in the mussel Mytilus edulis. Mar Ecol Prog Ser 55: $47-54$

Benson AJ, Marelli DC, Frischer ME, Danforth JM, Williams JD (2001) Establishment of the green mussel, Perna viridis (Linnaeus 1758) (Mollusca: Mytilidae) on the west coast of Florida. J Shellfish Res 20:21-29

Carlson DJ, Townsend DW, Hilyard AL, Eaton JF (1984) Effects of an intertidal mudflat on plankton of the overlying water column. Can J Fish Aquat Sci 41:1523-1528

Coughlan J (1969) The estimation of filtering rate from clearance of suspensions. Mar Biol 2:356-358

Crosby MP, Newell RIE, Langdon CJ (1990) Bacterial mediation in the utilization of carbon and nitrogen from detrital complexes by Crassostrea virginica. Limnol Oceanogr 35: 625-639

Dame RF (1996) Ecology of marine bivalves: an ecosystem approach. CRC Press, Boca Raton, FL

Davenport J, Smith RJJW, Packer M (2000) Mussels Mytilus edulis: significant consumers and destroyers of mesozooplankton. Mar Ecol Prog Ser 198:131-137

Dupuy C, Le Gall S, Hartmann HJ, Breret M (1999) Retention of ciliates and flagellates by the oyster Crassostrea gigas in French Atlantic coastal ponds: protists as a trophic link between bacterioplankton and benthic suspensionfeeders. Mar Ecol Prog Ser 177:165-175

Dupuy C, Pastoureaud A, Ryckaert M, Sauriau PG, Montanie $\mathrm{H}$ (2000a) Impact of the oyster Crassostrea gigas on a microbial community in Atlantic coastal ponds near La Rochelle. Aquat Microb Ecol 22:227-242

Dupuy C, Vaquer A, Lam-Hoai T, Rougier C, Mazouni N, Lautier J, Collos Y, Le Gall S (2000b) Feeding rate of the oyster Crassostrea gigas in a natural planktonic community of the Mediterranean Thau Lagoon. Mar Ecol Prog Ser 205:171-184

Gorham WT (1988) The energetic and nutritional contribution of glucose and glycine taken up from natural sea water by adult marine mussels. Mar Ecol 9:1-14

Horsted SJ, Nielsen TG, Riemann B, Pocksteen J, Bjornsen PK (1988) Regulation of zooplankton by suspension-feeding bivalves and fish in estuarine enclosures. Mar Ecol Prog Ser 48:217-224

Ingrao DA, Mikkelsen PM, Hicks DW (2001) Another introduced marine mollusk in the Gulf of Mexico: the IndoPacific green mussel, Perna viridis, in Tampa Bay, Florida. J Shellfish Res 20:13-19

Jasprica N, Caric M, Bolotin J, Rudenjak-Lukenda M (1997) The Mediterranean mussel (Mytilus galloprovincialis Lmk.) growth rate response to phytoplankton and microzooplankton population density in the Mali Ston Bay (Southern Adriatic). Period Biol 99:255-264

Jörgensen CB (1983) Patterns of uptake of dissolved aminoacids in mussels (Mytilus edulis). Mar Biol 73:177-182

Kimmerer WJ, Gartside E, Orsi JJ (1994) Predation by an introduced clam as the likely cause of substantial declines in zooplankton of San Francisco Bay. Mar Ecol Prog Ser 113:81-93

Kreeger DA, Newell RIE (1996) Ingestion and assimilation of carbon from cellulolytic bacteria and heterotrophic flagellates by the mussels Geukensia demissa and Mytilus edulis (Bivalvia, Mollusca). Aquat Microb Ecol 11:205-214

Kreeger DA, Newell RIE (2001) Seasonal utilization of different seston carbon sources by the ribbed mussel, Geukensia demissa (Dillwyn) in a mid-Atlantic salt marsh. J Exp Mar Biol Ecol 260:71-91

Langdon CJ, Newell RIE (1990) Utilization of detritus and bacteria as food sources by 2 bivalve suspension-feeders, 
the oyster Crassostrea virginica and the mussel Geukensia demissa. Mar Ecol Prog Ser 58:299-310

Le Gall S, Hassen MB, Le Gall P (1997) Ingestion of a bacterivorous ciliate by the oyster Crassostrea gigas: protozoa as a trophic link between picoplankton and benthic suspension-feeders. Mar Ecol Prog Ser 152:301-306

Loret P, Le Gall S, Dupuy C, Blanchot J, Pastoureaud A, Delesalle B, Caisey X, Jonquieres G (2000) Heterotrophic protists as a trophic link between picocyanobacteria and the pearl oyster Pinctada margaritifera in the Takapoto lagoon (Tuamotu Archipelago, French Polynesia). Aquat Microb Ecol 22:215-226

MacIsaac HJ, Sprules WG, Leach JH (1991) Ingestion of small-bodied zooplankton by zebra mussels (Dreissena polymorpha): can cannibalism on larvae influence population dynamics. Can J Fish Aquat Sci 48:2051-2060

MacIsaac HJ, Lonnee CJ, Leach JH (1995) Suppression of microzooplankton by zebra mussels: importance of mussel size. Freshw Biol 34:379-387

Manahan DT, Wright SH, Stephens GC (1983) Simultaneous determination of net uptake of 16 amino-acids by a marine bivalve. Am J Physiol 244:R832-R838

Møhlenberg F, Riisgård HU (1979) Filtration rate, using a new indirect technique, in 13 species of suspension-feeding bivalves. Mar Biol 54:143-147

Officer CB, Smayda TJ, Mann R (1982) Benthic filter feeding - a natural eutrophication control. Mar Ecol Prog Ser 9:203-210

Pace ML, Findlay SEG, Fischer D (1998) Effects of an invasive bivalve on the zooplankton community of the Hudson River. Freshw Biol 39:103-116

Page HM, Hubbard DM (1987) Temporal and spatial patterns of growth in mussels Mytilus edulis on an offshore platform-relationships to water temperature and food availability. J Exp Mar Biol Ecol 111:159-179

Park GS, Marshall HG (2000) The trophic contributions of rotifers in tidal freshwater and estuarine habitats. Estuar Coast Shelf Sci 51:729-742

Peterson CH, Black R (1987) Resource depletion by active suspension feeders on tidal flats-influence of local density and tidal elevation. Limnol Oceanogr 32:143-166

Prins TC, Small AC, Dame RF (1998) A review of the feedbacks between bivalve grazing and ecosystem processes. Aquat Ecol 31:349-359

Riemann B, Sorensen HM, Bjornsen PK, Horsted SJ, Jensen LM, Nielsen TG, Sondergaard M (1990) Carbon budgets of the microbial food web in estuarine enclosures. Mar Ecol Prog Ser 65:159-170

Roditi HA, Fisher NS (1999) Rates and routes of trace element uptake in zebra mussels. Limnol Oceanogr 44:1730-1749

Editorial responsibility: Roger Hughes (Contributing Editor), Bangor, Wales, UK
Roditi HA, Fisher NS, Sanudo-Wilhelmy SA (2000) Uptake of dissolved organic carbon and trace elements by zebra mussels. Nature 407:78-80

Seed R (1976) Ecology. In: Bayne BL (ed) Marine mussels: their ecology and physiology. Cambridge University Press, Cambridge, p 13-65

Sherr EB, Sherr BF, Fallon RD, Newell SY (1986) Small, aloricate ciliates as a major component of the marine heterotrophic nanoplankton. Limnol Oceanogr 31:177-183

Shumway SE, Cucci TL, Newell RC, Yentsch CM (1985) Particle selection, ingestion, and absorption in filter-feeding bivalves. J Exp Mar Biol Ecol 91:77-92

Shumway SE, Selvin R, Schick DF (1987) Food resources related to habitat in the scallop Placopecten magellanicus (Gmelin, 1791): a qualitative study. J Shellfish Res 6: 89-95

Siddall SE (1980) A clarification of the genus Perna (Mytilidae). Bull Mar Sci 30:858-870

Starkweather PL, Gilbert JJ (1977) Radiotracer determination of feeding in Brachionus calyciflorus: the importance of gut passage times. Arch Hydrobiol Beih Ergeb Limnol 8: 261-263

Stelfox CE, Burkill PH, Edwards ES, Harris RP, Sleigh MA (1999) The structure of zooplankton communities, in the 2 to $2000 \mu \mathrm{m}$ size range, in the Arabian Sea during and after the SW monsoon, 1994. Deep-Sea Res Part II 46:815-842

Stemberger RS, Gilbert JJ (1987) Defenses of planktonic rotifers against predators. In: Kerfoot WC, Sih A (eds) Predation: Direct and indirect impacts on aquatic communities. University Press of New England, Hanover, p 227-239

Wang WX, Fisher NS (1996) Assimilation of trace elements by the mussel Mytilus edulis: effects of diatom chemical composition. Mar Biol 125:715-724

Ward JE, Levinton JS, Shumway SE, Cucci T (1997) Site of particle selection in a bivalve mollusc. Nature 390: 131-132

Wong WH, Cheung SG (2001) Feeding rates and scope for growth of green mussels, Perna viridis (L.) and their relationship with food availability in Kat O, Hong Kong. Aquaculture 193:123-137

Wong WH, Levinton JS, Twining BS, Fisher NS (2003) Assimilation of micro- and mesozooplankton by zebra mussels: a demonstration of the food web link between zooplankton and benthic suspension feeders. Limnol Oceanogr 48: 308-312

Yúrera M, Parra G, Pascual E (1997) Energy content of rotifers (Brachionus plicatilis and Brachionus rotundiformis) in relation to temperature. Hydrobiologia 358:83-87

Zar JH (1996) Biostatistical analysis. Prentice Hall, Upper Saddle River, NJ

Submitted: September 5, 2002; Accepted: January 10, 2003

Proofs received from author(s): April 15, 2003 